\author{
MARIA DEPTUŁA \\ Uniwersytet Kazimierza Wielkiego \\ $w$ Bydgoszczy
}

\title{
POZNAWANIE SPOŁECZNEGO KONTEKSTU ROZWOJU PSYCHOSPOŁECZNEGO UCZNIÓW W KLASACH IV-VI
}

ABSTRACT. Deptuła Maria, Poznawanie społecznego kontekstu rozwoju psychospołecznego uczniów w klasach IV-VI [Getting to Know the Social Context of 4-6 Graders' Psychosocial Development]. Studia Edukacyjne nr 37, 2015, Poznań 2015, pp. 61-76. Adam Mickiewicz University Press. ISBN 978-83232-2967-4. ISSN 1233-6688. DOI: 10.14746/se.2015.37.5

The article presents two scales for researching the social context of 4-6 graders' psychosocial development. One focuses on the relations with peers from the same class while the other on the relations with teachers in a given class. Principles of social environmental psychology and Eric H. Erikson's notion of developmental goals constitute a theoretical basis of their construction. The scales include four dimensions representing the non-specific (important throughout one's life) developmental conditions. These are: sense of security; sense of ownership; sense of emotional contact and bond; sense of autonomy. They also include factors specific to the developmental phase that coincides with the period when children attend primary school. Those conditions facilitate developing a sense of competence and so two - sense of being valued and sense of support - were included. The scale for researching the context of psychosocial development in relations with other pupils consists of 19 items and the one pertaining to teacher relations includes 28 items. Both scales have a very high reliability (Cronbach's alfa is, respectively, 0.938 and 926; mean correlations between positions are 0.455 and 0.311 ). The scales may be used by class teachers or school counsellors. They may be also applied to the research of, e.g. the efficiency of educational and preventive influences.

Key words: scales, specific developmental conditions, non-specific developmental conditions, grades 4-6

\section{Wstęp}

Celem artykułu jest prezentacja konstrukcji skal do badania warunków rozwoju psychospołecznego uczniów w klasach IV-VI szkoły podstawowej, 
będąca przykładem rozwijanej przeze mnie koncepcji diagnozy warunków psychospołecznego rozwoju tworzonych dzieciom w różnym wieku i w różnych środowiskach (żłobek, przedszkole, szkoła podstawowa, gimnazjum). Najbardziej zaawansowane są prace nad diagnozą warunków rozwoju w klasie szkolnej w okresie późnego dzieciństwa. W artykule zostaną krótko scharakteryzowane podstawy teoretyczne konstrukcji skal do badania warunków rozwoju $\mathrm{w}$ relacjach $\mathrm{z}$ rówieśnikami $\mathrm{w}$ klasie szkolnej oraz $\mathrm{w}$ relacjach $\mathrm{z}$ nauczycielami uczącymi $\mathrm{w}$ danym zespole klasowym. Następnie zostaną zaprezentowane definicje wymiarów i przykładowe wskaźniki oraz omówiony sposób przeprowadzenia badań pilotażowych, jak też ich rezultaty świadczące o wybranych psychometrycznych właściwościach tych skal.

\section{Podstawy teoretyczne konstrukcji skal do badania społecznego kontekstu rozwoju psychospołecznego uczniów w klasach IV-VI}

Podstawą teoretyczną koncepcji diagnozy rozwoju psychospołecznego dzieci, której efektem są skale przedstawione w tym artykule jest teoria rozwoju człowieka, prezentowana przez Annę I. Brzezińską, której najistotniejsze z punktu widzenia celów tego artykułu twierdzenia zostaną tu tylko krótko scharakteryzowane. Autorka zwraca uwagę, że człowiek przez całe życie podlega oddziaływaniu sił ulokowanych na zewnątrz niego - $w$ środowisku fizycznym i społecznym oraz $\mathrm{w}$ nim samym, a siły te pozostają w ciągłej interakcji. $\mathrm{Na}$ "siły wewnętrzne" składają się nie tylko czynniki biologiczne, ale też kompetencje nabyte we wcześniejszych okresach życia (wiedza, umiejętności), które wpływają na zapotrzebowanie człowieka na dany rodzaj bodźców, oczekiwania wobec samego siebie i wobec otoczenia. $\mathrm{W}$ miarę rozwoju człowiek jest zdolny do wywierania coraz większego wpływu na swoje otoczenie i dostosowywania go do swoich planów i zamierzeń. Brzezińska przytacza pogląd H. Rudolpha Schaffera, iż „każdy człowiek poszukuje adekwatnej dla siebie niszy rozwoju, czyli takiego otoczenia, które 'pasuje' do jego garnituru genetycznego"2, co najlepiej pokazuje, jak ważna jest w tej koncepcji rola własnej aktywności człowieka w jego

${ }^{1}$ A.I. Brzezińska, Społeczna psychologia rozwoju, Warszawa 2000; tejże, Jak przebiega rozwój człowieka? [w:] Psychologiczne portrety człowieka. Praktyczna psychologia rozwojowa, red. A.I. Brzezińska, Gdańsk 2005, s. 21-39.

2 H.R. Schaffer, Psychologia dziecka, przekł. A. Wojciechowski, Warszawa 2005, za: A.I. Brzezińska, Jak przebiega rozwój człowieka? s. 23-24. 
rozwoju. Efekt rozwoju, czyli między innymi kompetencje, którymi dysponuje człowiek $w$ danym okresie swojego życia, zależy $z$ jednej strony od jego wewnętrznych zasobów, z drugiej zaś od zasobów zewnętrznych. Na zasoby wewnętrzne składa się to co oddziedziczył oraz co opanował w poprzednich okresach życia. Określają one jakość „wewnętrznego kontekstu rozwoju i poziom gotowości (w zakresie wiedzy i umiejętności oraz motywacji i zaangażowania) do podejmowania nowych zadań"3. Do zasobów zewnętrznych Brzezińska zalicza oferty i okazje do działania, system wsparcia istniejący $\mathrm{w}$ środowisku rozwijającej się jednostki, wymagania środowiska fizycznego i wymagania środowiska społecznego ${ }^{4}$.

Brzezińska charakteryzując społeczny kontekst rozwoju, wyodrębniła czynniki specyficzne i niespecyficzne. Miano specyficznych nadała tym, które są istotne $\mathrm{w}$ danym okresie życia. Należą do nich czynniki o szczególnym znaczeniu dla pomyślnej realizacji zadania rozwojowego przypadającego na daną fazę rozwoju. Czynniki niespecyficzne są istotne w każdym okresie życia, a zależą od jakości kontaktów jednostki z innymi ludźmi. Składa się na nie "poczucie bezpieczeństwa i pozostające z nim w opozycji poczucie kontroli nad sytuacją oraz poczucie więzi w opozycji do poczucia autonomii" 5 . Czynniki niespecyficzne wpływają między innymi na działania człowieka. Jeśli wysokiemu poczuciu bezpieczeństwa i zadowoleniu z silnych więzi z innymi towarzyszy wysokie poczucie sprawstwa i autonomii, to człowiek jest odważny, otwarty i ciekawy świata, aktywny i zaangażowany w poznawanie swojego otoczenia. Niesprzyjające rozwojowi są zakłócenia równowagi $\mathrm{w}$ tym dynamicznym układzie. Bardzo wysokie poczucie bezpieczeństwa i silna potrzeba więzi z innymi przy niskim poczuciu kontroli nad sobą i otoczeniem oraz niskim poczuciem autonomii Brzezińska nazywa "układem ryzyka”, podobnie jak niskie poczucie bezpieczeństwa i niezaspokojenie potrzeby przynależności przy jednoczesnym wysokim poczuciu kontroli nad sytuacją i poczuciem autonomii w działaniu.

Konsekwencją takiego niesprzyjającego rozwojowi układu w pierwszej z opisanych wersji może być nadmierna ostrożność, nadmierna obawa przed nieznanym, bierność i zależność od poleceń, opinii, zgody innych osób na działania, które podejmuje jednostka ${ }^{6}$. W przypadku drugiej wersji można, jak sądzę, spodziewać się dużej aktywności podejmowanej zgodnie $\mathrm{z}$ własnymi potrzebami, marzeniami czy planami, lecz w poczuciu zagrożenia i osamotnienia.

\footnotetext{
${ }^{3}$ A.I. Brzezińska Jak przebiega rozwój człowieka? s. 24.

4 Tamże, s. 23-24.

5 Tamże, s. 30.

${ }^{6}$ Tamże, s. 32.
} 
O znaczeniu czynników nazwanych przez Brzezińską niespecyficznymi pisał wiele lat temu Wiesław Łukaszewski, przedstawiając je w kontekście szans na samorealizację i akcentując ich zależność od kultury, w której żyjemy, w tym procesów socjalizacji i edukacji ${ }^{7}$. Rolę każdego z nich z osobna omawia się chyba w każdym podręczniku psychologii rozwojowej. Jednak dla mnie inspiracją do uwzględnienia tych czynników jako wymiarów konstruowanych skal stało się dopiero ujęcie przedstawione przez Brzezińską. Dzięki niemu uzmysłowiłam sobie ich wzajemną zależność i fakt, że jest to układ dynamiczny, a zakłócenia równowagi w nim mają wielokrotnie opisane $\mathrm{w}$ literaturze następstwa istotne dla pedagogów, których zadaniem jest tworzenie dzieciom warunków sprzyjających rozwojowi. $Z$ tego powodu poczucie bezpieczeństwa, kontaktu emocjonalnego i więzi, autonomii i sprawstwa uczyniłam wymiarami konstruowanych skal.

Kolejne dwa wymiary, które wzięłam pod uwagę - poczucie bycia docenianym i poczucie wsparcia - są konsekwencją przyjęcia koncepcji zadań rozwojowych Erika Eriksona. Zgodnie z nią, w okresie uczęszczania do szkoły podstawowej dziecko „uczy się (...) zyskiwać uznanie dzięki wykonywaniu pewnych rzeczy"8. Rozwija

w sobie przemyślność i pracowitość - tzn. dopasowuje się do obcych praw rządzących światem narzędzi i instrumentów. Doprowadzenie czynności wytwarzania do końca stanowi cel, który stopniowo wypiera zachcianki i pragnienia związane z zabawą ${ }^{9}$.

Dziecko uczy się też „,czerpać przyjemność z ukończenia pracy, co osiąga dzięki wytężonej uwadze i wytrwałości"10. Zagrożeniem rozwoju w tej fazie jest

poczucie niestosowności i niższości. Jeśli nie ma ono nadziei na opanowanie narzędzia i umiejętności lub nie ufa własnej pozycji wśród partnerów, może zniechęcić się do utożsamienia z nimi oraz ze światem instrumentów ${ }^{11}$.

Innym zagrożeniem są „,ograniczenia nakładane przez człowieka na siebie samego oraz zawężanie swych horyzontów tak, by obejmowały jedynie jego pracę"12.

\footnotetext{
7 W. Łukaszewski, Szanse rozwoju osobowości, Warszawa 1984.

8 E.H. Eriskon, Dzieciństwo i społeczeństwo, przekł. M. Hejmej, Poznań 1997, s. 269.

${ }_{9}$ Tamże, s. 270.

10 Tamże.

11 Tamże.

12 Tamże, s. 271.
} 
Błażej Smykowski analizując w pracach Eriksona opis konfliktu produktywność vs poczucie niższości przypadającego na tę fazę rozwoju pisze, że doświadczanie poczucia niższości będące efektem porażek $\mathrm{w}$ panowaniu nad rzeczywistością, w dążeniu do bycia użytecznym czy perfekcyjnej realizacji zadań

może motywować do pokonywania trudności, być źródłem podstawowej dla tego okresu siły życiowej, jaką jest kompetencja panowania nad rzeczywistością i podzielania z innymi aktualności (...), ale i przyczyną poważnego kryzysu13.

Zwraca uwagę na podstawowe znaczenie w tym okresie relacji dziecka z nauczycielem, który między innymi „może zapobiec poważnemu kryzysowi, jeśli prawidłowo rozpozna uzdolnienia i wysiłki dziecka oraz nim pokieruje"14.

To twierdzenie oraz udokumentowana $\mathrm{w}$ literaturze rola nauczycieli w kształtowaniu się samooceny dziecka, jego poczucia własnej wartości, a w konsekwencji poczucia kompetencji stanowiło podstawę uwzględnienia w diagnozie zewnętrznego kontekstu rozwoju przekonań dziecka wskazujących na to, że nauczyciel je docenia i że może ono liczyć na jego wsparcie ${ }^{15}$.

$\mathrm{Z}$ analizy dynamiki społecznej sytuacji rozwoju w okresach dzieciństwa i dorastania przeprowadzonej przez Smykowskiego wynika, że na II etapie edukacji, kiedy środowisko nauczania staje się bardziej zróżnicowane na skutek wprowadzenia nauczania przedmiotowego (różnorodność i zmienność treści nauczania i nauczycieli) poczucie stałości powinna dawać dziecku grupa rówieśnicza. Uznanie grupy nabiera szczególnego znaczenia ${ }^{16}$, dlatego docenianie przez rówieśników i przekonanie, że można na nich liczyć są równie ważnymi specyficznymi czynnikami rozwoju, jak docenianie i wsparcie nauczyciela. Wiele innych argumentów potwierdzających rolę rówieśników w tym okresie życia znajduje się w każdym podręczniku psychologii rozwojowej.

Zdaję sobie sprawę, że wymienione zmienne szczegółowe są tylko fragmentem społecznego kontekstu rozwoju uczniów w klasach IV-VI. Ich wybór wynika z przekonania, że są to te obszary, na które każdy wychowawca może mieć wpływ. Uwzględnienie ich w programie pracy wychowawczej s. 171.

13 B. Smykowski, Psychologia kryzysów w kulturowym rozwoju dzieci i młodzieży, Poznań 2012,

14 Tamże.

15 Szerzej na ten temat m.in.: K. Appelt, Wiek szkolny. Jak rozpoznać potencjat dziecka? [w:] Psychologiczne portrety człowieka, s. 259-301; P. Wiliński, Wiek szkolny. Jak rozpoznać ryzyko i jak pomagać? [w:] Psychologiczne portrety człowieka, s. 304-343.

16 B. Smykowski, Psychologia kryzysów, s. 205-206. 
z klasą i sprawdzanie zachodzących w wyniku jego realizacji zmian, dzięki opracowanym skalom, może ułatwić modyfikowanie pracy wychowawczej w klasie.

\title{
Operacjonalizacja wymiarów skal do badania społecznego kontekstu rozwoju psychospołecznego w klasach IV-VI
}

\author{
Augustyn Bańka pisze, że zależność
}

człowiek-środowisko analizować można na poziomie wewnętrznego doświadczenia jednostki w postaci percepcji, odczuć, emocji, motywacji, wartości oraz zakresu możliwego wpływu (...). Indywidualne mechanizmy odbioru środowiska nadają $\mathrm{mu}$ określone znaczenia, a te z kolei wyznaczają kierunek aktywności człowieka17.

Konsekwencją przyjęcia przeze mnie tego założenia jest badanie atrybucji każdego ucznia dotyczących intencji i zachowań rówieśników i nauczycieli wobec niego.

Atrybucja w ujęciu Bańki oznacza „przypisywanie czegoś komuś lub czemuś"18. W pojęciu przypisywanie - jak pisze Bańka - zawarte jest założenie, że nasze spostrzeganie innych i siebie, a w rezultacie funkcjonowanie $\mathrm{w}$ relacjach interpersonalnych,

jest efektem tego, jakie cechy, właściwości czy stany przypisujemy szeroko rozumianemu otoczeniu oraz sobie samym. Stoi za tym przesłanka, że proces społecznego funkcjonowania jednostki jest odzwierciedleniem subiektywnego procesu strukturalizowania społecznego świata ${ }^{19}$.

Zgodnie $\mathrm{z}$ tym założeniem pytania $\mathrm{w}$ kwestionariuszach ankiety zaczynają się zwykle od sformułowania: „Jak myślisz, ile osób z Twojej klasy chciałoby, żebyś..." , albo "Jak myślisz, ilu nauczycielom, z którymi masz lekcje w szkole zależy na tym, żebyś...."

W obu kwestionariuszach badani mieli do wyboru pięć możliwych odpowiedzi. $\mathrm{W}$ ankiecie dotyczącej relacji z rówieśnikami: nikt, jedna osoba, kilka osób, wiele osób, prawie wszyscy ${ }^{20}$. W kwestionariuszu odnoszącym

17 A. Bańka, Społeczna psychologia środowiskowa, Warszawa 2002, s. 27.

18 Tamże, s. 75.

19 Tamże.

${ }^{20}$ Inspirację dla sformułowania 2 pytań i opracowania kafeterii odpowiedzi stanowiła dla mnie ankieta dotycząca odrzucenia rówieśniczego opracowana przez A.Y. Mikami, M.A. Bo- 
się do relacji z nauczycielami do wyboru były odpowiedzi: żadnemu, jednemu, kilku, większości, wszystkim. Różnica w sformułowaniu ostatniej możliwości przedstawianej badanym do wyboru jest zamierzona. Uznałam, że w klasach, które zwykle liczą około 25 osób nie jest ważne, by przekonanie dotyczące występowania danego zachowania czy intencji dotyczyło wszystkich uczniów, lecz by dotyczyło większości lub prawie wszystkich. Grupa nauczycieli, z którymi uczniowie w klasach IV-VI mają kontakt jest znacznie mniejsza, a zadaniem nauczyciela jest tworzenie każdemu uczniowi w klasie warunków sprzyjających jego rozwojowi. Zatem, można oczekiwać, że każdy z nich będzie postrzegany jako osoba wywiązująca się $\mathrm{z}$ tego zadania.

Poczucie bezpieczeństwa zdefiniowałam za Abrahamem Maslowem²1 jako przekonanie o życzliwości rówieśników i nauczycieli, braku zagrożenia $\mathrm{z}$ ich strony, o sprawiedliwym traktowaniu zgodnie $\mathrm{z}$ ustalonymi regułami. Warunki istotne dla poczucia bezpieczeństwa podane przez Maslowa obejmują także możliwość kontroli nad zdarzeniami wynikającą z uporządkowania świata i ograniczenia chaosu. Jednak wątek kontroli nad istotnymi dla jednostki zdarzeniami stanowi w mojej koncepcji osobny wymiar.

Skala dotycząca postrzegania warunków do zaspokojenia potrzeby bezpieczeństwa $\mathrm{w}$ relacjach $\mathrm{z}$ rówieśnikami obejmuje 3 pytania $\mathrm{z}$ odwróconą punktacją odpowiedzi, bowiem wskaźniki dotyczą: bycia obiektem dokuczania, wyśmiewania, złośliwości; przekonania, że rówieśnicy mogą specjalnie zrobić badanemu/badanej przykrość, że jego/jej porażka może im sprawić radość. Ten sam wymiar w relacjach z nauczycielami badany jest za pomocą 5 pytań. Odpowiedzi na dwa z nich mają odwróconą punktację. Są to odpowiedzi dotyczące tego, jak wielu nauczycieli wzbudza w osobie badanej strach, obawę związaną z ocenianiem jej pracy lub często mówi do niej podniesionym głosem. Trzy pozostałe pytania dotyczą postrzegania życzliwości, sprawiedliwości i określenia przez nauczyciela reguł pracy i zachowania na lekcjach.

Poczucie sprawstwa w ujęciu Łukaszewskiego oznacza zdolność do "spostrzegania siebie jako czynnika sprawczego”, jako „konstruktora zdarzeń”, , przekonanie o własnych możliwościach ingerowania w bieg zdarzeń w taki sposób, by zmieniać ich przebieg i zmieniać ich skutki"22.

ucher, K. Humphreys, Prevention of Peer Rejection Through a Classroom-Level Intervention in Middle School, The Journal of Primary Prevention, 2005, 26, 1, s. 5-23.

21 A. Maslow, Motywacja i osobowość, Warszawa 1990, s. 79.

22 W. Łukaszewski, Szanse rozwoju osobowości, s. 435. 
Ten wymiar $\mathrm{w}$ relacjach $\mathrm{z}$ rówieśnikami badany jest za pomocą 3 pytań dotyczących wpływu na to, co się dzieje w klasie, jak traktują osobę badaną rówieśnicy oraz na podejmowane przez klasę decyzje. Wymiar poczucia sprawstwa $\mathrm{w}$ relacjach $\mathrm{z}$ nauczycielami obejmuje 5 pytań dotyczących możliwości samodzielnej pracy na lekcjach, związku pomiędzy pracą badanego/badanej na lekcjach i w domu z otrzymywanymi ocenami i posiadanymi umiejętnościami, związku opinii nauczycieli o badanym/badanej z jego/jej zachowaniem oraz przekonania o możliwości wpływania na zasady obowiązujące na lekcjach.

Kazimierz Obuchowski zdefiniował kontakt emocjonalny jako stosunek dwustronny, „w którym człowiek czuje, że jest przedmiotem zainteresowania, że inni współbrzmią z jego własnymi uczuciami" ${ }^{23}$. W konstrukcji tego wymiaru skali wykorzystałam tylko to, co osoba badana otrzymuje od innych, a nie to, co sama im oferuje.

Możliwość zaspokojenia tej potrzeby $\mathrm{w}$ relacjach $\mathrm{z}$ rówieśnikami badają 3 pytania dotyczące liczby osób w klasie, z którymi osoba badana lubi współpracować, dla których ważna jest jej obecność i dobre samopoczucie. W odniesieniu do relacji z nauczycielami, pytania (5) dotyczą liczby nauczycieli, dla których ważne są przeżycia osoby badanej na lekcji, jej dobre samopoczucie, okazujących mu sympatię i słuchających jej wypowiedzi oraz przekonania, że zależy im na tym, by mogła odnieść sukces w nauce.

W definicji pojęcia autonomii za najważniejsze uznałam odczucie wolności wyboru, niezależności od innych ${ }^{24}$. W relacjach z rówieśnikami poczucie autonomii badają 3 pytania, które dotyczą przekonania, że badany/badana nie zostanie wykluczony/a z grupy, jeśli nie będzie podobny/a do nich pod względem zainteresowań, ubioru i zachowania. W relacjach $\mathrm{z}$ nauczycielami wymiar autonomii badany jest także za pomocą 3 pytań. Dotyczą one liczby przedmiotów, na których badany/badana może realizować swoje pomysły, zdecydować o swojej pracy, o wyborze osób, z którymi będzie wspólnie pracował/a jeśli nauczyciel organizuje pracę w grupach.

\section{Badania pilotażowe}

Badania sprawdzające tę wersję skal (wcześniejsza miała 4 kategorie odpowiedzi oraz nieco inaczej sformułowane pytania i możliwe odpowiedzi

${ }^{23}$ K. Obuchowski, Psychologia dą̇̇eń ludzkich, wyd. 4, zmienione i rozszerzone, Warszawa 1983, s. 178-179.

${ }^{24}$ M. Kofta, D. Doliński, Poznawcze podejście do osobowości, [w:] Psychologia. Podręcznik akademicki, red. J. Strelau, Gdańsk 2001, s. 565. 
dotyczące relacji z nauczycielami) przeprowadzone zostały metodą papierołówek w czerwcu 2015 roku przy współpracy z pracownikami Miejskiego Ośrodka Edukacji Nauczycieli w Bydgoszczy ${ }^{25}$. Do badań wybrano trzy szkoły, kierując się średnią punktów uzyskanych przez uczniów danej szkoły w sprawdzianie na zakończenie VI klasy przeprowadzonym w roku 2014. W szkołach o najniższych i przeciętnych wynikach objęto badaniami uczniów z dwóch klas IV i dwóch klas VI (wszystkie klasy z tego poziomu nauczania). W szkole, której średni wynik testu mieścił się w przedziale wyników wysokich, badaniami objęto dwie klasy IV i jedną VI, jedyną jaka w tym czasie była. Badanie objęło łącznie 207 uczniów, jednak z powodów, o których mowa niżej oraz $\mathrm{z}$ uwagi na brak odpowiedzi na pojedyncze pytania do analizy zakwalifikowałam 159 ankiet dotyczących warunków rozwoju w relacjach z rówieśnikami i 158 ankiet dotyczących tych samych warunków w relacjach z nauczycielami.

Badania poprzedziło uzyskanie zgody rodziców na udział ich dziecka $w$ badaniu. To zadanie wykonali wychowawcy klas zapoznani z celami badań i narzędziami badawczymi. W jednej ze szkół zgody nie uzyskano od jednego rodzica.

Badania przeprowadziły osoby spoza szkoły (pracownicy i doktorantka UKW, w tym autorka tego artykułu oraz pracownicy MOEN26). Uczniowie zostali poinformowani o celach badań, o możliwości odmowy wypełnienia każdej $\mathrm{z}$ ankiet, zrezygnowania $\mathrm{w}$ dowolnym momencie prowadzenia badań. Otrzymali też informację, jak będą one przebiegały (5 kwestionariuszy wypełnianych $\mathrm{w}$ różnym czasie) oraz o potrzebie połączenia odpowiedzi każdego ucznia udzielonych w kolejnych dniach. Dzięki temu uczniowie bez problemu zrozumieli procedurę, która została zastosowana w celu zapewnienia im pełnej anonimowości. $W$ pierwszym dniu badań losowali kartkę z siedmiocyfrowym numerem kodowym (kody wygenerowano za pomocą programu Excel), wpisywali numer na swojej ankiecie, a następnie karteczkę z kodem chowali do małej koperty, którą opatrywali imieniem i nazwiskiem lub wybranym przez siebie symbolem. Kopertę zaklejali. Członek samorządu klasowego zbierał koperty z kodami uczniów tej klasy

${ }^{25}$ Badania tu omawiane są fragmentem badań prowadzonych w związku z realizacją Strategii Rozwoju Edukacji w Bydgoszczy. W szkołach podstawowych oprócz autorki tego artykułu prowadzą je jeszcze dwie osoby z pomocą przygotowanych przez siebie narzędzi. Badania dotyczące wzmacniania rezyliencji uczniów grup z ryzyka prowadzi dr Wioletta Junik, a badania dotyczące współpracy szkoły z rodzicami dr Blanka Poćwiardowska.

${ }^{26}$ Autorka składa podziękowania Dyrektorowi i Pracownikom MOEN oraz koordynatorce badań Pani Dorocie Wojtczak. 
do dużej koperty, zaklejał i odnosił do sejfu w sekretariacie szkoły. Przed kolejnym badaniem przynosił kopertę swojej klasy, otwierał ją i rozdawał koperty z kodami koleżankom i kolegom. Zastosowana procedura spotkała się z uznaniem uczniów.

Uczniowie sprawdzali, czy rzeczywiście ich prawo do odmowy będzie respektowane odmawiając wypełnienia ankiety. Zjawisko to wystąpiło tylko w szkole, której wyniki mieściły się w najniższej staninie i dotyczyło przede wszystkim uczniów powtarzających klasę. Kiedy się przekonali, że osoba prowadząca badanie przyjmuje spokojnie i ze zrozumieniem ich decyzję, nie wywiera nacisku, jedynie zachęca do przeczytania ankiety przed podjęciem ostatecznej decyzji, czasem zmieniali zdanie i wypełniali ankietę. Niektórzy uczniowie odmówili wypełnienia pierwszej ankiety (dotyczyła relacji z rówieśnikami), a wypełnili którąś z następnych lub wszystkie kolejne.

\section{Wyniki}

Analizy statystyczne wykonałam za pomocą programu Statistica 12, korzystając z licencji zakupionej przez UKW. Skala do badania warunków rozwoju psychospołecznego $\mathrm{w}$ relacjach z rówieśnikami dla 19 itemów ${ }^{27}$ osiągnęła wysoką rzetelność (alfa Cronbacha $=0,938$ ). Średnia korelacji między pozycjami wynosi 0,455 .

Skala do badania warunków rozwoju psychospołecznego w relacjach z nauczycielami ma również wysoką rzetelność (alfa Cronbacha $=0,920$ ) i liczy 28 itemów ${ }^{28}$. Średnia korelacji między pozycjami równa się 0,311. Gdybym zdecydowała się na usunięcie kolejnych dwóch itemów, to rzetelność skali wzrosłaby do 0,926, a średnia korelacji między pozycjami do 0,342. Na tym etapie pracy nad skalami nie decyduję się jednak na ich usuwanie.

Teoretyczną trafność obu skal sprawdzano porównując zróżnicowanie wyników w zależności od typu szkoły, do której uczęszczają badani. Szkoła, której średnie wyniki mieściły się w najniższej staninie mieści się w środowisku zdominowanym przez rodziny o bardzo niskim statusie socjoekonomicznym. W wielu rodzinach występują poważne problemy związane

27 Narzędzie zastosowane w badaniach składało się z 21 itemów. Dwa zostały usunięte w wyniku analizy rzetelności, ze względu na niskie współczynniki korelacji pozycji.

${ }^{28}$ Narzędzie zastosowane w badaniach składało się z 30 itemów. Dwa zostały usunięte z wyżej podanych powodów. 
z nadużywaniem alkoholu i uzależnieniem od niego. Wiele dzieci wychowuje się $\mathrm{w}$ rodzinach niepełnych, dotkniętych bezrobociem i różnymi przejawami patologii. Można więc przyjąć, że $\mathrm{w}$ tych rodzinach często nie ma podstawowych warunków do powstania bezpiecznego przywiązania w okresie wczesnego dzieciństwa, ani warunków sprzyjających realizacji kolejnych zadań rozwojowych, przypadających na okres poniemowlęcy i przedszkolny. W rezultacie, dzieci wkraczają do szkoły gorzej przygotowane do nawiązywania relacji z rówieśnikami i nauczycielami, niż ich rówieśnicy z rodzin zapewniających im warunki sprzyjające rozwojowi. Oznacza to między innymi niższy poziom rozwoju teorii umysłu pozwalającej na rozumienie sytuacji społecznych, $\mathrm{w}$ tym zwłaszcza motywów postępowania innych ludzi, empatyczne reagowanie na ich emocje. U dzieci wychowujących się $\mathrm{w}$ takich rodzinach częściej występują też zaburzenia $\mathrm{w}$ rozwoju kompetencji emocjonalnych, $w$ tym zwłaszcza zdolności do kontroli emocji, oraz $\mathrm{w}$ rozwoju kompetencji społecznych umożliwiających zaspokajanie swoich potrzeb $\mathrm{w}$ relacjach $\mathrm{z}$ innymi ludźmi. Dowody na poparcie tych twierdzeń przedstawiła między innymi autorka niniejszego artykułu29.

Funkcjonowanie dzieci żyjących $w$ takich środowiskach prowadzi też do specyficznego przetwarzania informacji o innych ludziach oraz powstawania szeregu stereotypów i uprzedzeń wobec nich, co utrudnia dziecku obiektywną ocenę ich intencji. Dzieci te będąc gorzej przygotowane do przystosowania się do wymagań stawianych w szkole zarówno co do nauki, jak i zachowania przy jednoczesnym niedopasowaniu środowiska szkolnego do ich potrzeb i możliwości, mają też poważne trudności w relacjach z nauczycielami, których przejawami bywa poczucie krzywdy i żal, agresja, poczucie bezradności ${ }^{30}$.

Wyniki testów (jednoczynnikowa ANOVA ${ }^{31}$ ) świadczą o tym, że typ szkoły różnicuje warunki psychospołecznego rozwoju uczniów zarówno w relacji z uczniami $(p=0,0003)$, jak i nauczycielami $(p=0,013)$.

Na rycinie 1 widoczne są średnie dla uczniów uczących się w szkole o najniższych wynikach w sprawdzianie na koniec klasy VI (kod 1), wynikach przeciętnych $(\operatorname{kod} 2)$ i najwyższych $(\operatorname{kod} 3)$.

${ }^{29}$ M. Deptuła, Odrzucenie rówieśnicze. Profilaktyka i terapia, Warszawa 2013, rozdz. 2 i 3.

30 Tamże, rozdz. 1 i 4.

${ }^{31}$ Skośność i kurtoza mieści się w przedziale od plus do minus 1, w związku z tym zastosowano $\mathrm{w}$ analizach testy parametryczne. 


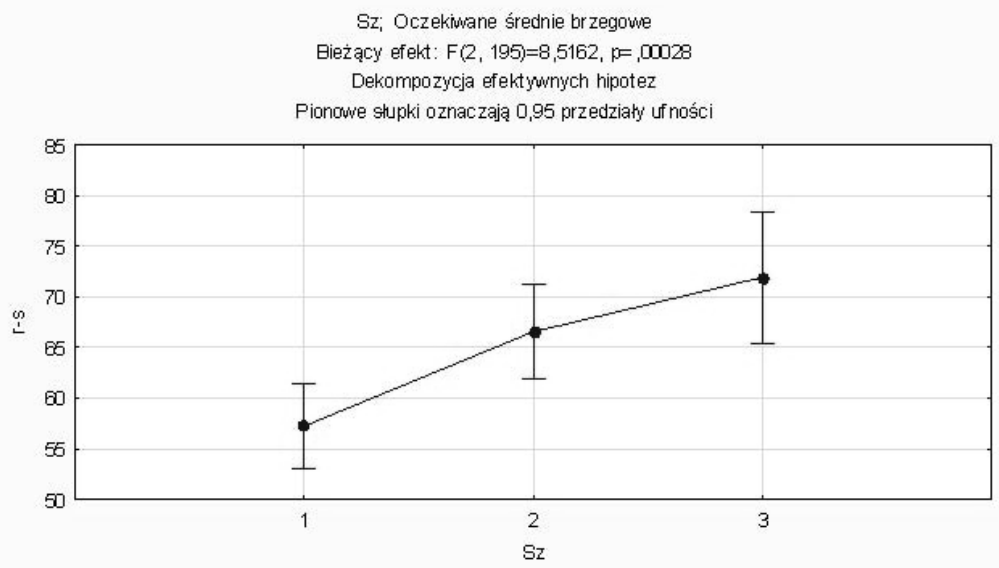

Ryc. 1. Społeczny kontekst rozwoju psychospołecznego w klasach IV-VI - relacje z rówieśnikami w zależności od typu szkoły

Porównanie wyników uzyskanych przez uczniów z poszczególnych szkół parami świadczy o tym, że istotne są tylko różnice między szkołą, w której uczniowie osiągają wyniki niskie a szkołą o przeciętnych wynikach $(\mathrm{t}=-2,942 ; \mathrm{df}=159 ; \mathrm{p}=0,004)$ oraz między szkołą o najniższych wynikach i szkołą o wynikach wysokich $(\mathrm{t}=-3,548 ; \mathrm{df}=124 ; \mathrm{p}=0,0005)$.

$\mathrm{Na}$ rycinie 2 widoczne są rezultaty porównania wyników dla relacji $\mathrm{z}$ nauczycielami $\mathrm{w}$ zależności od typu szkoły. Porównanie wyników uzyskanych przez uczniów z poszczególnych szkół parami świadczy o tym, że istotne są - podobnie jak w przypadku relacji z rówieśnikami - różnice mię-

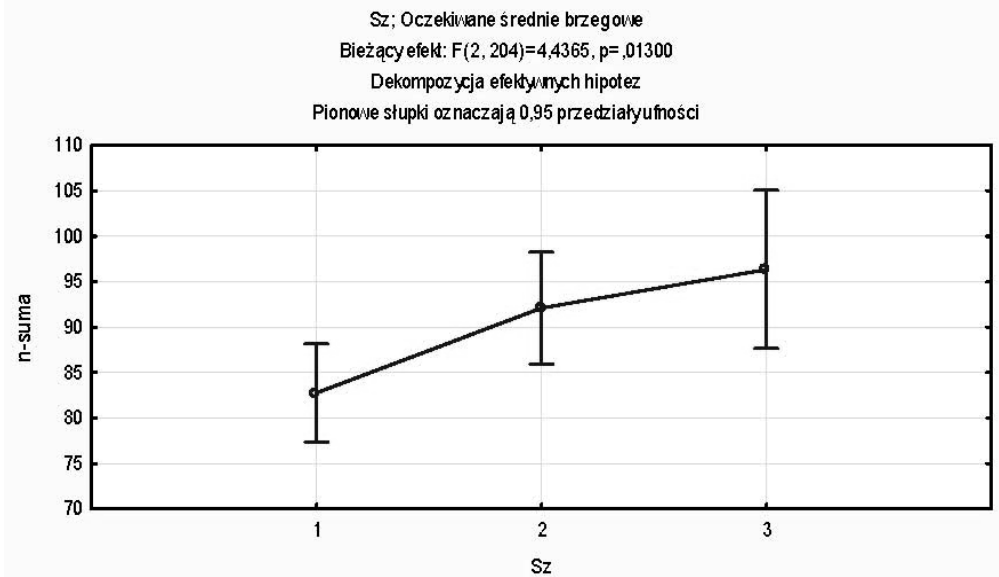

Ryc. 2. Społeczny kontekst rozwoju psychospołecznego w klasach IV-VI - relacje z nauczycielami w zależności od typu szkoły 
dzy szkołą, w której uczniowie osiągają najniższe wyniki a szkołą o przeciętnych wynikach $\mathrm{w}$ sprawdzianie na koniec VI klasy $(\mathrm{t}=-2,143$; $\mathrm{df}=168$; $\mathrm{p}=0,034)$ oraz między szkołą o najniższych i najwyższych wynikach w sprawdzianie na koniec VI klasy $(t=-2,689 ; d f=131 ; p=0,008)$.

W tabeli zamieszczonej poniżej znajduje się zestawienie wartości średniej i odchylenia standardowego dla każdej skali.

Tabela 1

Społeczny kontekst rozwoju psychospołecznego uczniów klas IV i VI a typ szkoły

\begin{tabular}{|c|c|c|c|c|c|c|}
\hline & \multicolumn{5}{|c|}{ Społeczny kontekst rozwoju psychospołecznego uczniów } \\
\hline & \multicolumn{3}{|c|}{ Relacje z rówieśnikami } & \multicolumn{3}{c|}{ Relacje z nauczycielami } \\
\hline $\begin{array}{c}\text { Typ } \\
\text { szkoły }\end{array}$ & $\begin{array}{c}\text { śred- } \\
\text { nia }\end{array}$ & $\begin{array}{c}\text { odchylenie } \\
\text { standardo- } \\
\text { we }\end{array}$ & $\begin{array}{c}\text { średnia } \\
\text { przypadają- } \\
\text { ca na 1 item }\end{array}$ & $\begin{array}{c}\text { śred- } \\
\text { nia }\end{array}$ & $\begin{array}{c}\text { odchylenie } \\
\text { standardo- } \\
\text { we }\end{array}$ & $\begin{array}{c}\text { średnia } \\
\text { przypadają- } \\
\text { ca na 1 item }\end{array}$ \\
\hline 1 & 51,5 & 21,4 & 2,71 & 82,8 & 28,2 & 2,96 \\
\hline 2 & 60,9 & 18,4 & 3,21 & 92,1 & 28,2 & 3,29 \\
\hline 3 & 65,0 & 13,1 & 3,42 & 96,4 & 19,5 & 3,44 \\
\hline
\end{tabular}

Wartości odchylenia standardowego dla porównywanych grup wyróżnionych ze względu na typ szkoły w przypadku relacji z rówieśnikami maleją wraz ze wzrostem wyników sprawdzianu na zakończenie klas VI. Atrybucje uczniów co do zachowań i intencji kolegów i koleżanek z klasy wobec nich w szkole o wysokich wynikach sprawdzianu na koniec klasy VI są najmniej zróżnicowane.

Warto też zwrócić uwagę na wartości średnich. Przy 19 pytaniach, w których odpowiedziom badanych przypisywano punkty od 1 do 5 , gdzie 5 oznaczało wynik najbardziej korzystny, maksimum skali wynosi 95 . Taki wynik oznaczałby, że badani przypisują pozytywne intencje i zachowania wobec siebie prawie wszystkim kolegom i koleżankom ze swojej klasy.

W przypadku atrybucji dotyczących intencji i zachowań nauczycieli zróżnicowanie odpowiedzi jest identyczne w szkole o najniższych wynikach sprawdzianu na zakończenie VI klas i wynikach przeciętnych. Znacznie mniej zróżnicowane są atrybucje uczniów ze szkoły o najwyższych wynikach na koniec klasy VI. Maksymalna wartość tej skali wynosi 140 i oznacza, że uczniowie przypisują pozytywne intencje i zachowania wobec siebie wszystkim uczącym ich w tym roku szkolnym nauczycielom.

Ze względu na nierówną liczbę itemów w obu skalach w tabeli 1 znajduje się także średnia przypadająca na jeden item. Pozwala ona zobaczyć, że atrybucje uczniów w szkole o niskich wynikach na koniec klasy VI są nieco bardziej pozytywne wobec nauczycieli niż wobec rówieśników. W pozostałych dwóch szkołach to zróżnicowanie jest mniejsze. Niżej zamieszczony 
wykres uwidacznia różnice dla wszystkich badanych uczniów w zakresie atrybucji co do intencji i zachowań rówieśników $(\mathrm{R})$ i nauczycieli $(\mathrm{N})$ odnoszących się do poczucia bezpieczeństwa (B), kontaktu emocjonalnego (E), poczucia autonomii (A), poczucia sprawstwa (S), doceniania (D) i wsparcia (W).

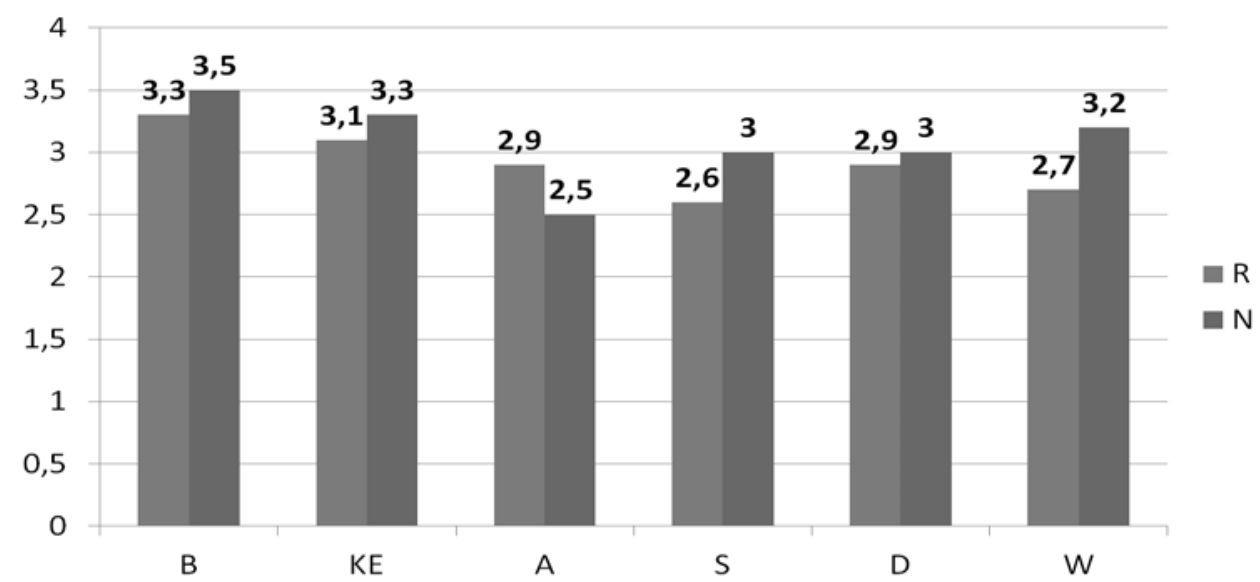

Ryc. 3. Średnie przypadające na jeden item dla poszczególnych wymiarów społecznego kontekstu rozwoju - $\mathrm{w}$ relacjach $\mathrm{z}$ rówieśnikami i $\mathrm{w}$ relacjach $\mathrm{z}$ nauczycielami

Średnie przypadające na jeden item świadczą o tym, że w relacjach z nauczycielami uczniowie mają lepsze warunki rozwoju niż $\mathrm{w}$ relacjach $\mathrm{z}$ rówieśnikami, z wyjątkiem poczucia autonomii. W tym wymiarze odnotowano najniższy wynik $w$ przypadku relacji z nauczycielami.

Spośród wszystkich wymiarów branych pod uwagę w tym badaniu najwyższe wyniki odnotowano $\mathrm{w}$ przypadku poczucia bezpieczeństwa oraz kontaktu emocjonalnego i to zarówno $\mathrm{w}$ relacjach $\mathrm{z}$ nauczycielami, jak i w relacjach z rówieśnikami. Wysoki jest także wynik dotyczący poczucia wsparcia.

W relacjach z rówieśnikami najniższy wynik odnotowano na wymiarach poczucie sprawstwa i poczucie wsparcia, co oznacza, że uczniowie często nie są przekonani o własnych możliwościach wpływania na to, jak są traktowani przez kolegów i koleżanki z klasy oraz na decyzje podejmowane w klasie. Nie bardzo mogą też liczyć, że w trudnej sytuacji otrzymają pomoc.

Na podstawie analizy średnich przypadających na jeden item nie można powiedzieć, czy ta średnia jest efektem tego, że większość badanych udzieliła takiej odpowiedzi, czy też zespoły klasowe są skrajnie zróżnicowane. Taką jakościową analizę przedstawię w innym kolejnym artykule. 


\section{Wnioski}

Prezentowane skale mają obiecujące wartości psychometryczne. Nie wszystkie mogą być tu przedstawione ze względu na objętość niniejszego tekstu. Wydaje się, że mogą uzupełnić warsztat diagnostyczny pedagogów szkolnych i wychowawców klas, ułatwiając przeprowadzanie anonimowych badań $\mathrm{w}$ zespołach klasowych, których rezultaty mogą stanowić podstawę projektowania pracy wychowawczej. Efektem ich stosowania może być też zmiana myślenia nauczycieli. Zamiast koncentrować uwagę na tym, co mogę zrobić $\mathrm{z}$ tym dzieckiem, co jest - jak się zdaje - najczęstszym sposobem myślenia, mogą skłonić do refleksji nad tym, jak mogę zmienić swoje zachowanie $\mathrm{w}$ kontakcie $\mathrm{z}$ dzieckiem. Zamiast analizować negatywne zachowania dziecka i zastanawiać się nad jego deficytami, lepiej się zastanowić, jakie intencje może ono przypisywać rówieśnikom i nauczycielom, jak interpretować ich zachowania i jakie $\mathrm{w}$ związku z tym przeżywać uczucia. Wystarczy przeanalizować, jak rozkładają się odpowiedzi uczniów w klasie, jakie są indywidualne średnie wartości przypadające na poszczególne wymiary, a w ramach wymiarów na poszczególne pytania. Bez wiedzy o tym, czyje są poszczególne odpowiedzi w klasie, nauczyciel może się zastanowić nad własnym sposobem funkcjonowania $\mathrm{w}$ relacjach $\mathrm{z}$ uczniami, zaplanować pracę nad rozwojem swoich umiejętności interpersonalnych i wychowawczych, zmiany w prowadzeniu lekcji oraz pracę z klasą zmierzającą do stworzenia $\mathrm{w}$ zespole klasowym warunków bardziej sprzyjających rozwojowi uczniów.

Na podstawie wyników badań pilotażowych poprzedniej wersji tych skal współpracowałam, przez kilka miesięcy, z nauczycielami w jednej szkole podstawowej nad projektowaniem wyżej wymienionych zmian. Efekty tej współpracy zostaną przedstawione w oddzielnej publikacji.

\section{BIBLIOGRAFIA}

Appelt K., Wiek szkolny. Jak rozpoznać potencjat dziecka? [w:] Psychologiczne portrety człowieka. Praktyczna psychologia rozwojowa, red. A.I. Brzezińska, Gdańskie Wydawnictwo Psychologiczne, Gdańsk 2005.

Bańka A., Społeczna psychologia środowiskowa, Wydawnictwo Naukowe Scholar, Warszawa 2002.

Brzezińska A.I., Społeczna psychologia rozwoju, Wydawnictwo Naukowe Scholar, Warszawa 2000.

Brzezińska A.I., Jak przebiega rozwój człowieka? [w:] Psychologiczne portrety człowieka. Praktyczna psychologia rozwojowa, red. A.I. Brzezińska, Gdańskie Wydawnictwo Psychologiczne, Gdańsk 2005. 
Deptuła M., Odrzucenie rówieśnicze. Profilaktyka i terapia, Wydawnictwo Naukowe PWN, Warszawa 2013, rozdz. 2 i 3.

Eriskon E.H., Dzieciństwo i społeczeństwo, przekł. M. Hejmej, Dom Wydawniczy Rebis, Poznań 1997.

Kofta M., Doliński D., Poznawcze podejście do osobowości, [w:] Psychologia. Podręcznik akademicki, red. J. Strelau, Gdańskie Wydawnictwo Psychologiczne, Gdańsk 2001.

Łukaszewski W., Szanse rozwoju osobowości, Książka i Wiedza, Warszawa 1984.

Maslow A., Motywacja i osobowość, Instytut Wydawniczy Pax, Warszawa 1990.

Mikami A.Y., Boucher M.A., Humphreys K., Prevention of Peer Rejection Through a Classroom-Level Intervention in Middle School, The Journal of Primary Prevention, 2005, $26,1$.

Obuchowski K., Psychologia dążeń ludzkich, wyd. 4, zmienione i rozszerzone, Państwowe Wydawnictwo Naukowe, Warszawa 1983.

Schaffer H.R., Psychologia dziecka, przekł. A. Wojciechowski, Wydawnictwo Naukowe PWN, Warszawa 2005.

Smykowski B., Psychologia kryzysów w kulturowym rozwoju dzieci i młodzieży, Wydawnictwo Naukowe UAM, Poznań 2012.

Wiliński P., Wiek szkolny. Jak rozpoznać ryzyko i jak pomagać? [w:] Psychologiczne portrety człowieka. Praktyczna psychologia rozwojowa, red. A.I. Brzezińska, Gdańskie Wydawnictwo Psychologiczne, Gdańsk 2005. 